\title{
Job Satisfaction among Support Staff in Michigan Academic Libraries
} Julie Voelck

\begin{abstract}
In a partial replication of a 1989 study conducted by Coleen Parmer and Dennis East in Ohio, a job satisfaction questionnaire was distributed in 1994 to support staff in thirteen state-supported academic libraries in Michigan. Results indicate that while support staff are satisfied with supervision, the nature of their work, coworkers, and benefits, they are dissatisfied with opportunities for promotion, pay, and contingent rewards. The means of several dimensions of job satisfaction varied significantly by the staff variables of experience, education, position title, union representation, full-or part-time work, and working directly with users. There are some notable differences in the results of this study as compared to the results reported by Parmer and East. Based on the results, some ways to improve support staff job satisfaction are suggested.
\end{abstract}

he contributions of paraprofessionals, technical assistants, and other support staff are vital to the successful operation of academic libraries in carrying out service missions. In many academic libraries, support staff comprise a majority of all staff, while librarians are in the minority. In a national study of paraprofessional staff in college and university libraries reported in 1992, Larry R. Oberg and others found that libraries are employing more paraprofessionals and fewer librarians than in the past. ${ }^{1}$ The most recent data published by the Association of College and Research Libraries (ACRL) and the Association of Research Libraries (ARL) support this finding. Of 106 reporting ACRL libraries, nonprofessional staff comprised a median of 44 percent of the total staff, and, combined with student staff, a median of 72 percent of the total. ${ }^{2}$ In ARL libraries, the median percentage of nonprofessional staff was 51 percent of the total, and, with student staff, the median percent- age was 73 percent. $^{3}$ At the same time, the overall number of staff-in all positions-appears to be declining steadily. Beverly P. Lynch and Jo Ann Verdin found in their study of two ARL libraries that the total number of full-time library staff decreased throughout the 1980s, and this pattern seems to be continuing for many academic libraries in the 1990 s. $^{4}$

The problem of declining budgets in an era of rising costs for subscriptions, automation, and other library materials is often cited as a cause of staff reductions, and all indications are that the economic uncertainty faced by academic libraries will continue for some time to come. This situation, combined with such factors as the increase in quantity and complexity of technology and the demands of teaching, research, and governance activities for librarians in many academic libraries, has led to an increase in the number and level of essential tasks and duties that have become primarily the responsibility of support staff. Although this has been reported often in 
technical services, it is also happening in public services, where support staff are frequently the first (and sometimes the only) contact with patrons and fulfill an exigent and critical information-providing and public relations role for their libraries.

In his article on job satisfaction in a changing library environment, Jack A. Siggins provides three compelling arguments to justify making the job satisfaction of library staff a primary concern. First, some research has shown a relationship between job satisfaction and staff performance and productivity. Second, staff who are chronically dissatisfied with their jobs may manifest such negative behaviors as chronic absenteeism and high turnover. Third, library administrators should concern themselves with job satisfaction simply because they care about the well-being of the people with whom they work. ${ }^{5}$

Given that support staff comprise a large percentage of the total staff and hold a significant degree of responsibility for carrying out essential duties and providing primary services in most libraries, and given the assumption that the effectiveness of a library in fulfilling service goals and objectives depends to some extent on the morale of its staff, it is important to gain an understanding of the areas of job satisfaction and dissatisfaction for support staff and to use this knowledge to develop ways to improve or enhance the work environment.

\section{LITERATURE REVIEW}

Since the mid-1970s, several studies on job satisfaction in libraries have been reported. William J. Vaughn and J. D. Dunn carried out a comparative study of six university libraries in Texas using the Job Description Index (JDI). They found that the scores of neither a particular library nor of a specific department differed significantly from the rest on the total index or on five job dimensionspay, the work itself, supervision, people, and promotion. ${ }^{6}$

Steven Seokho Chwe compared the satisfaction score results of reference librarians and catalogers on the Minne- sota Satisfaction Questionnaire (MSQ) in ninety-one university libraries. Although he found no difference in overall job satisfaction, he did find that the catalogers were significantly less satisfied than reference librarians with the opportunities inherent in their work for creativity, variety, and social service. ${ }^{7}$

George P. D'Elia analyzed 288 MSQs completed by recent library school graduates. He found that the supervisory climate and factors intrinsic to the work itself, such as opportunities for achievement, creativity, and recognition, were most closely related to job satisfaction. $^{8}$

In 1983 Beverly P. Lynch and Jo Ann Verdin reported the results of their survey of full-time staff in three research libraries. Among the findings were that staff in reference departments reported significantly more satisfaction than staff in all other departments but acquisitions, and that staff with more experience reported more satisfaction than staff with less experience. ${ }^{9}$ In 1987 Lynch and Verdin reported on the results of a replication of their study. They again found staff in reference departments were relatively more satisfied with their jobs. ${ }^{10}$ Circulation staff, however, reported higher job satisfaction in the second study than in the first. ${ }^{11}$

Ilene F. Rockman surveyed California State University system faculty and librarians using the MSQ. She found that decision making (which was positively influenced by years of experience) and autonomy were highly correlated with job satisfaction, but that gender was not. ${ }^{12}$

Carol D. Billings and Betty Kern interviewed fifty paraprofessionals in eleven Louisiana libraries. Respondents were most dissatisfied with their salaries; pressure brought on by increases in technology, lack of opportunity for promotion, and inadequate fringe benefits were also sources of dissatisfaction. They expressed satisfaction with intrinsic rewards, the physical and intellectual environment of the library, supervision, and working with patrons. ${ }^{13}$

A number of studies of job satisfaction in libraries have been reported just since 
1990. Donna K. Fitch administered the JDI to support staff in Alabama academic libraries. One of her findings was that staff with ten or more years of experience were the least satisfied and staff with less than a year of experience were the most satisfied with their chances for promotion. ${ }^{14}$

The results of a survey of librarians and library assistants conducted by $\mathrm{Pa}$ tricia A. Kreitz and Annegret Ogden indicated that library assistants were dissatisfied with the "reward structure" of their jobs. Respondents also expressed a need for more intrinsic rewards, such as the appreciation of others for one's work..$^{15}$

Margaret S. Schneider surveyed and interviewed the staff of a large urban public library system, the majority of whom were paraprofessionals and worked in public services. They reported satisfaction with the nature of the work itself, coworkers, immediate supervisors, and working directly with patrons. ${ }^{16}$ They reported dissatisfaction with communications between staff and management, and a majority identified heavy workloads and understaffing as serious problems. ${ }^{17}$

Leigh Estabrook, Lisa Mason, and Sara Suelflow distributed questionnaires and conducted selective focus group interviews with 1,371 ARL library staff, 801 of whom were support staff. Communication was identified as an area of dissatisfaction for support staff; some respondents specifically noted thinking that they were not given the same level of feedback on matters related to their work as were librarians. They also thought they were not given the chance to optimally use their talents and education in their work. ${ }^{18}$

To gather data on the roles, status, and working conditions of library staff, Oberg and others conducted a national survey of library directors. Among their findings: paraprofessionals were often more qualified than required for their positions; and high-level skills were often expected of support staff, many of whom carried out duties that were in the past performed by librarians. ${ }^{19}$

In a survey of more than two hundred academic library support staff in Wis- consin, Cathleen C. Palmini found that automation was a source of job satisfaction for over half of the respondents, although 38 percent said the training they received was inadequate. ${ }^{20}$ Causes of job satisfaction identified by the respondents included working with patrons, aspects of the work itself, coworkers, and working with computers. Causes of dissatisfaction included computer downtime and slow response time, heavy workloads, and understaffing. ${ }^{21}$

In 1989 Coleen Parmer and Dennis East distributed a questionnaire to support staff in twelve state-supported academic libraries in Ohio. ${ }^{22}$ Using as part of their questionnaire the Job Satisfaction Survey (JSS) developed by Paul E. Spector for employees of human service, public, or nonprofit organizations, Parmer and East examined scores on a scale measuring overall job satisfaction, as well as scores on nine satisfaction dimensions or subscales: benefits, communication, contingent rewards, coworkers, operational procedures, pay, promotion, supervision, and the work itself. ${ }^{23}$ They also examined the influence on the mean satisfaction scores of eleven library support staff variables: area of work, experience, work with patrons, job classification, full- versus part-time work, gender, commitment, education, library size, promotions received, and supervisory responsibility. Support staff respondents scored as satisfied on the overall job satisfaction scale and on the subscales of supervision, coworkers, the work itself, benefits, and pay; they scored as dissatisfied on the subscales of promotion, contingent rewards, procedures, and communication. ${ }^{24}$ Other findings include that public services staff were significantly more satisfied on the overall scale and four subscales than technical services staff; staff with less experience scored higher on overall satisfaction and four subscales than staff with more experience; staff who work with patrons were significantly more satisfied than those who do not on the overall scale and four subscales; library assistants and office workers were the 
most satisfied and technical assistants the least on the overall scale and three subscales; and part-time staff were significantly more satisfied on the overall scale and three subscales than full-time staff..$^{25-29}$ As Parmer and East point out, the different instruments and methodologies used to examine job satisfaction in previous studies make comparisons difficult. ${ }^{30}$ Their own research, by introducing the use of the JSS-which appears to be wellsuited to the measurement of job satisfaction of library personnel-provides an opportunity for further study and meaningful comparison.

\section{DEFINITIONS OF CONCEPTS}

\section{Support Staff}

Several different titles and general position designations have been used over the years to identify library employees who do not hold librarian positions, including paraprofessionals, associates, technical assistants, and nonprofessionals. As in the Parmer and East study, the designation support staff was chosen because it is general enough to encompass most library personnel except librarians, student assistants, and maintenance or custodial staff. Also, it seems to be preferred by nonlibrarian staff themselves, as indicated by the subtitles of Library Mosaics: The Magazine for Support Staff and Associates: The Electronic Library Support Staff Journal.

Specific support staff position titles for this study are based upon the three categories recommended by the American Library Association:

- Library Associate or Associate Specialist-in general, requires the minimum of a bachelor's degree, or the equivalent in education and library experience; may involve a high level of responsibility, normally within established procedures and techniques and with some supervision by a librarian, but with a significant degree of independent judgment; and may involve the supervision of other staff.

- Library Technical Assistant (LTA) or Technical Assistant - normally requires at least two years of library experi- ence; responsible for carrying out duties supportive to associates and/or librarians, following established policies and procedures; and may involve the supervision of other LTAs or clerical staff.

- Clerk or Secretary-normally requires the minimum of a high school diploma, often supplemented with business or commercial courses and on-the-job training and experience; involves carrying out assignments as defined by the individual library or library department. ${ }^{31}$

\section{Job Satisfaction}

Spector defined job satisfaction as a staff member's "emotional-affective response to a job or specific aspects of the job. ${ }^{32} \mathrm{He}$ further described job satisfaction as representing "a cluster of feelings about the job" as well as an overall attitude that is a combination of the individual feelings that make up the cluster. ${ }^{33}$ He then selected nine specific individual feelings or job satisfaction dimensions because they were most commonly cited in the literature and he found them to be most meaningful. ${ }^{34}$ They are broadly defined for this study as follows:

1. Promotion-opportunities for and perceived fairness in awarding them.

2. Pay-amount of salary and perceived fairness or equity.

3. Contingent rewards-recognition, appreciation, and praise given by others (especially one's supervisor) for work well done.

4. Communication-interchange of information verbally or in writing.

5. Operational procedures-policies, procedures, rules and regulations, "red tape."

6. Benefits-medical coverage, pension, paid vacation, other paid leaves of absence.

7. Coworkers-perceived competence, helpfulness, and friendliness of people with whom one works.

8. Nature of the workitself-intrinsic interest level, variety, amount, and opportunity for achievement and creativity. 
9. Supervision-perceived competency, fairness, and administrative and management skills of one's immediate supervisor.

\section{METHODOLOGY}

This study of the job satisfaction of support staff in Michigan in part replicates the Ohio study conducted by Parmer and East. As did Parmer and East, the author used Spector's Job Satisfaction Survey (JSS) as part of the questionnaire. On the JSS, the nine dimensions or subscales of job satisfaction are operationalized into four items each, for a total of thirty-six items, some of which are worded in a positive and some in a negative direction. For example, the subscale "pay" is represented by four items and placed inconsecutively on the questionnaire: (1) "I feel I am being paid a fair amount for the work I do" (positive); (2) "Raises are too few and far between" (negative); (3) "I feel unappreciated by the organization when I think about what they pay me" (negative); and (4) "I feel satisfied with my chances for salary increases" (positive). The author revised Spector's wording in two ways: references to "supervisor" were changed to "immediate supervisor" to avoid confusion for respondents who have more than one supervisor; and references to "benefits" were changed to "benefits package" to avoid the possibility that respondents may think of the term as referring to other kinds of nonfringe job benefits. Each one of the thirty-six items is measured on a Likert-type scale of six response choices: (1) disagree very much, (2) disagree moderately, (3) disagree slightly, (4) agree slightly, (5) agree moderately, (6) agree very much. After inverting the codes for the negatively worded items (i.e., on the negatively worded items 1 becomes 6,2 becomes 5 , etc.), the score on each item ranges from one to six points. Since each subscale consists of four items, scores for a subscale range from 4 (indicating lowest satisfaction) to 24 (indicating highest satisfaction). With a midpoint score of 14 , scores indicating some degree of dissatisfaction range from 4 to 14 , and scores indicating some degree of satisfaction range from
14 to 24 . An overall job satisfaction score consists of the sum of all thirty-six subscale scores and ranges from a low of 36 to a high of 216. With a midpoint of 126 , scores indicating overall dissatisfaction range from 36 to 126 , and scores indicating overall satisfaction range from 126 to 216.

Originally, Spector administered the JSS to over 3,000 public and human service employees. He compared his results to those of other studies and concluded that there is evidence for the instrument's reliability and construct validity; because it was normalized on data obtained from public service employees, the JSS is better suited to respondents who work in public service occupations than other job satisfaction surveys. ${ }^{35}$ The JSS further appears to fulfill the instrument selection criteria identified by Vaughn and Dunn: it measures several dimensions of job satisfaction as well as the overall concept; it applies to a variety of public and human service occupations; it is sensitive to variations in attitude (by using the Likert-type scale); it has been tested for reliability and validity; it is relatively brief and easy to score; and normative data-from Spector's large sample-are available. ${ }^{36}$ One weakness of the JSS is that some respondents do not complete all thirty-six items because they think they have already provided an answer on another similarsounding item. Spector, as well as Parmer and East, reported experiencing this problem. In an attempt to avoid it, an instruction in bold-face type at the top of the appropriate section of the questionnaire cautions respondents to answer all of the questions, even if they think they have already provided the answer with another response.

In this study, the slightly revised JSS is the second part of the two-part questionnaire. The first part consists of nine questions designed to gather information about nine characteristics of library support staff and their positions: job classification (based on the standard titles recommended by the ALA, in order to avoid the difficulties of trying to compare local titles that vary considerably 
from library to library); full-time or parttime status; union representation; experience in current position; experience in all library positions; level of education; primary work area; direct contact with library patrons; and use of computers. (The author will provide a copy of the questionnaire upon request.)

To obtain permission to conduct the survey, the author sent letters to the chief administrators of the fifteen state-supported academic libraries in Michigan and followed up by telephone. She also asked in the letter for the number of support staff employed in each library and the name of a contact person who would be willing to distribute the questionnaires. Thirteen of the fifteen statesupported academic library systems participated in the study. The overall response rate was about 62 percent.

\section{RESULTS}

Table 1 presents the job satisfaction mean scores and standard deviations for all respondents on the nine subscales and overall scale for three data sets: the Michigan study; Parmer and East's study in Ohio; and Spector's public and human service employees. The overall job satisfaction scores are similar for each study; academic library support staff, like public service employees in general, find their jobs generally satisfying.

The mean scores in table 1 indicate that Michigan respondents are most satisfied with the immediate supervision they receive and are also quite satisfied with the nature of the work itself and with their coworkers. Benefits and operational procedures are only somewhat satisfying areas. The mean score for communication is very close to the midpoint, indicating that some respondents are dissatisfied and some satisfied on this subscale. Michigan respondents are most dissatisfied with their chances for promotion and level of pay. They are also somewhat dissatisfied with contingent rewards. As Parmer and East pointed out, staff who lack an M.L.S. degree and consequently cannot pass from support staff ranks to librarian positions may feel unhappy with the lack of opportunity for promotion and with salaries which may be low, especially in comparison to the pay received by the librarians with whom they work. ${ }^{37}$ The mean score on contingent rewards indicates that they may think their work is unappreciated and perhaps undervalued at times because they are not librarians. The mean score on communication may indicate that, for some of the same reasons, some

TABLE 1

COMPARISON OF JOB SATISFACTION MEANS AND STANDARD DEVIATIONS

\begin{tabular}{lccccccc}
\hline & \multicolumn{3}{c}{ Michigan } & \multicolumn{7}{c}{$\begin{array}{c}\text { Ohio } \\
(N=422)\end{array}$} & \multicolumn{2}{c}{$\begin{array}{c}\text { Spector } \\
(N=3,067)\end{array}$} \\
\cline { 2 - 8 } $\begin{array}{l}\text { Overall Satisfaction } \\
\text { and Subscales }\end{array}$ & Valid $N$ & Mean & \multicolumn{1}{c}{$S D$} & Mean & \multicolumn{1}{c}{$S D$} & Mean & $S D$ \\
\hline Supervision & 368 & 19.13 & 4.74 & 18.41 & 5.57 & 19.9 & 4.6 \\
Work itself & 371 & 18.56 & 4.35 & 16.58 & 4.27 & 19.2 & 4.4 \\
Coworkers & 362 & 17.02 & 4.28 & 17.44 & 4.02 & 18.8 & 3.7 \\
Benefits & 364 & 16.11 & 4.78 & 16.29 & 4.40 & 13.1 & 5.0 \\
Operational & & & & & & & \\
$\quad$ procedures & 366 & 14.85 & 4.11 & 14.19 & 4.47 & 12.5 & 4.6 \\
Communication & 368 & 14.09 & 4.50 & 14.07 & 4.77 & 14.0 & 5.0 \\
Contingent rewards & 363 & 13.16 & 5.00 & 13.90 & 5.35 & 13.4 & 5.1 \\
Pay & 368 & 11.93 & 5.16 & 14.93 & 4.26 & 10.5 & 5.1 \\
Promotion & 367 & 9.28 & 4.20 & 10.15 & 4.85 & 11.5 & 5.1 \\
Overall & 325 & 134.13 & 26.05 & 135.96 & 29.22 & 133.1 & 27.9 \\
\hline
\end{tabular}


TABLE 2

JOB SATISFACTION BY YEARS OF EXPERIENCE IN ALL LIBRARY POSITIONS: SIGNIFICANT SUBSCALES AND OVERALL SCALE

\begin{tabular}{|c|c|c|c|}
\hline & Years of Experience & Valid $N$ & Mean \\
\hline Overall scale & $\begin{array}{c}11-15 \\
6-10 \\
16+ \\
0-5 \\
\text { F ratio } 4.91\end{array}$ & $\begin{array}{r}65 \\
82 \\
77 \\
101\end{array}$ & $\begin{array}{l}134.34 \\
131.60 \\
131.48 \\
128.10 \\
p<.01\end{array}$ \\
\hline Work itself & $\begin{array}{c}11-15 \\
16+ \\
6-10 \\
0-5 \\
\text { F ratio } 8.67\end{array}$ & $\begin{array}{r}71 \\
86 \\
94 \\
120\end{array}$ & $\begin{array}{c}19.84 \\
19.72 \\
18.24 \\
17.20 \\
p<.001\end{array}$ \\
\hline Operational procedures & $\begin{array}{c}16+ \\
11-15 \\
6-10 \\
0-5 \\
\text { F ratio } 7.01 \\
\end{array}$ & $\begin{array}{r}85 \\
69 \\
95 \\
117\end{array}$ & $\begin{array}{c}14.47 \\
14.43 \\
14.14 \\
12.64 \\
p<.001 \\
\end{array}$ \\
\hline Communication & $\begin{array}{c}0-5 \\
16+ \\
6-10 \\
11-15 \\
\text { F ratio } 4.92 \\
\end{array}$ & $\begin{array}{r}119 \\
86 \\
92 \\
71\end{array}$ & $\begin{array}{c}15.37 \\
13.56 \\
13.38 \\
13.51 \\
p<.01 \\
\end{array}$ \\
\hline Coworkers & $\begin{array}{c}11-15 \\
16+ \\
6-10 \\
0-5 \\
\text { F ratio } 3.16\end{array}$ & $\begin{array}{r}71 \\
82 \\
91 \\
118\end{array}$ & $\begin{array}{l}17.31 \\
16.85 \\
16.64 \\
16.24 \\
p<.05 \\
\end{array}$ \\
\hline Benefits & $\begin{array}{c}11-15 \\
16+ \\
6-10 \\
0-5 \\
F \text { ratio } 3.00 \\
\end{array}$ & $\begin{array}{r}70 \\
85 \\
93 \\
116 \\
\end{array}$ & $\begin{array}{l}16.91 \\
16.60 \\
16.38 \\
15.05 \\
p<.05 \\
\end{array}$ \\
\hline
\end{tabular}

respondents perceive themselves as outside the communication loop in their libraries, and perhaps they feel excluded from planning, decision-making, and problem-solving activities that can directly affect them and the services they are responsible for providing.

An analysis of variance run on the Michigan data set using SPSS/PC+ shows that seven of the nine support staff characteristics have within their categories statistically significant differences in the mean scores on specific subscales and the overall job satisfaction scale. The $F$ ratios, significance levels, and mean scores for these seven variables are presented in tables 2 through 8.

Whether looking at all library positions held by respondents or at the currently held position only, library experience is strongly related to job satisfaction. Tables 2 and 3 show that the fewer the years of experience, the less satisfied support staff are overall and with the work itself, operational procedures, coworkers, and benefits. On the operational procedures subscale, $0-5$ years is the only category to have a mean score in the dissatisfied range on 


\section{TABLE 3}

JOB SATISFACTION BY YEARS OF EXPERIENCE IN CURRENT POSITION: SIGNIFICANT SUBSCALES AND OVERALL SCALE

\begin{tabular}{|c|c|c|c|}
\hline 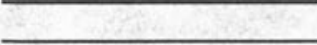 & Years of Experience & Valid $N$ & Mean \\
\hline Overall scale & $\begin{array}{c}11-15 \\
6-10 \\
16+ \\
0-5 \\
\text { F ratio } 5.00 \\
\end{array}$ & $\begin{array}{r}42 \\
79 \\
41 \\
162\end{array}$ & $\begin{array}{l}134.38 \\
133.63 \\
130.49 \\
129.05 \\
p<.01 \\
\end{array}$ \\
\hline Work itself & $\begin{array}{c}16+ \\
11-15 \\
6-10 \\
0-5 \\
\text { F ratio } 6.18 \\
\end{array}$ & $\begin{array}{r}47 \\
46 \\
89 \\
187 \\
\end{array}$ & $\begin{array}{c}20.66 \\
19.22 \\
18.71 \\
17.80 \\
p<.001\end{array}$ \\
\hline Communication & $\begin{array}{c}0-5 \\
16+ \\
11-15 \\
6-10 \\
F \text { ratio } 4.44 \\
\end{array}$ & $\begin{array}{r}186 \\
47 \\
46 \\
87\end{array}$ & $\begin{array}{c}14.85 \\
14.21 \\
13.37 \\
12.87 \\
p<.01\end{array}$ \\
\hline Operational procedures & $\begin{array}{c}6-10 \\
11-15 \\
16+ \\
0-5 \\
\text { F ratio } 4.32 \\
\end{array}$ & $\begin{array}{r}89 \\
44 \\
47 \\
184 \\
\end{array}$ & $\begin{array}{c}14.52 \\
14.36 \\
14.30 \\
13.16 \\
p<.01\end{array}$ \\
\hline Contingent rewards & $\begin{array}{c}0-5 \\
16+ \\
11-15 \\
6-10 \\
F \text { ratio } 3.32 \\
\end{array}$ & $\begin{array}{r}182 \\
45 \\
46 \\
88 \\
\end{array}$ & $\begin{array}{c}13.82 \\
13.60 \\
12.78 \\
11.85 \\
p<.05 \\
\end{array}$ \\
\hline Benefits & 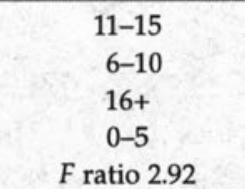 & $\begin{array}{r}46 \\
88 \\
46 \\
182\end{array}$ & $\begin{array}{c}17.46 \\
16.78 \\
16.04 \\
15.47 \\
p<.05\end{array}$ \\
\hline
\end{tabular}

both experience in current position and experience in all library positions. Perhaps this finding can be explained by the difficulty and complexity of many library support staff positions; with more experience staff may become more comfortable with procedures. However, respondents with the least experience are most satisfied with organizational communication. In fact, respondents with $0-5$ years' experience in all library positions are the only ones to score in the satisfied range on this subscale; and respondents with $0-5$ years' experience in their current posi- tions are one of only two groups to score in the satisfied range. All other groups with more experience score in the dissatisfied range. This may reflect the unfulfilled expectation of support staff that they will be included in policy, procedure, and decision-making activities as they gain experience and become more proficient in their work.

Union representation is another variable that is related to the job satisfaction of the respondents, as shown in table 4. Support staff whose positions are represented by a formal, organized union are significantly more satisfied on the over- 
TABLE 4

JOB SATISFACTION BY UNION REPRESENTATION: SIGNIFICANT SUBSCALES AND OVERALL SCALE

\begin{tabular}{lccc}
\hline & Union Representation & Valid $N$ & Mean \\
\hline Overall scale & Yes & 229 & 131.85 \\
& No & 93 & 128.76 \\
& F ratio 5.63 & & $p<.05$ \\
\hline Communication & No & 108 & 15.49 \\
& Yes & 256 & 13.48 \\
& Fratio 15.69 & & $p<.001$ \\
\hline Benefits & Yes & 255 & 16.64 \\
& No & 105 & 14.87 \\
& Fratio 10.57 & & $p<.01$ \\
\hline Operational procedures & Yes & 255 & 14.15 \\
& No & 107 & 12.92 \\
& Fratio 10.07 & & $p<.01$ \\
\hline Promotion & No & 108 & 12.62 \\
& Yes & 255 & 11.54 \\
& Fratio 8.97 & 109 & $p<.05$ \\
\hline Contingent rewards & No & 250 & 13.96 \\
& Yes & & 12.77 \\
& F ratio 4.36 & & $p<.05$ \\
\hline
\end{tabular}

all scale as well as on the benefits and operational procedures subscales. Both union and nonunion staff score in the satisfied range on benefits, but on operational procedures union staff are slightly satisfied while nonunion staff are dissatisfied. However, staff represented by a union are significantly less satisfied on the subscales of promotion, contingent rewards, and communication, although both groups score in the dissatisfied range on promotion and contingent rewards. On communication, the mean score for nonunion staff is in the satisfied range, while the mean score for union staff is in the dissatisfied range. These results refute the assumption that unionization always provides opportunity for greater job satisfaction, but they are difficult to explain. It may be that practices designed to safeguard jobs for union employees can at the same time lock them into job ranks and make promotions to other positions unlikely. Also, union employees sometimes find themselves in adversarial relationships with library administrators, and this may lead to some dissatisfaction with communications. Then, too, the union may offer its members opportunity for communication and participation in decision making, setting up the expectation that the library will offer similar chances for participation; if this does not happen, dissatisfaction may occur.

Job satisfaction is related to the fulltime or part-time status of the employees, as table 5 shows. In three significant subscales-benefits, the work itself, and operational procedures-full-time staff are significantly more satisfied than part-time staff. On the benefits and operational procedures subscales, full-time staff score in the satisfied range, while part-time staff score in the dissatisfied range. Since many part-time staff do not receive fringe benefits and may not have gained the experience or received the training to become familiar and comfortable with complex departmental procedures, these mean scores are not surprising. On the communication subscale, however, not only are parttime staff significantly more satisfied 
TABLE 5

JOB SATISFACTION BY FULL-TIME AND PART-TIME WORK: SIGNIFICANT SUBSCALES AND OVERALL SCALE

\begin{tabular}{lccc}
\hline & Full- or Part-Time & Valid $N$ & Mean \\
\hline Overall scale & Full-time & 257 & 131.94 \\
& Part-time & 68 & 127.59 \\
& F ratio 9.17 & & $p<.01$ \\
\hline Benefits & Full-time & 287 & 16.85 \\
& Part-time & 77 & 13.35 \\
& F ratio 35.67 & & $p<.001$ \\
\hline Work itself & Full-time & 288 & 19.02 \\
& Part-time & 83 & 16.94 \\
& F ratio 15.33 & & $p<.001$ \\
\hline Operational procedures & Full-time & 286 & 14.14 \\
& Part-time & 80 & 12.54 \\
& F ratio 14.31 & & $p<.001$ \\
\hline Communication & Part-time & 81 & 15.36 \\
& Full-time & 287 & 13.73 \\
& F ratio 8.42 & & $p<.01$ \\
\hline
\end{tabular}

TABLE 6

JOB SATISFACTION BY STANDARD JOB TITLE: SIGNIFICANT SUBSCALES

\begin{tabular}{lccc}
\hline & Standard Title & Valid & Mean \\
\hline Communication & Clerical & 116 & 14.70 \\
& Technical & 140 & 14.52 \\
& Associate & 110 & 12.85 \\
& F ratio 6.01 & & $p<.01$ \\
\hline Operational procedures & Associate & 110 & 14.42 \\
& Technical & 140 & 13.89 \\
& Clerical & 113 & 12.93 \\
& F ratio 5.74 & & $p<.01$ \\
\hline Work itself & Associate & 111 & 19.46 \\
& Technical & 141 & 18.47 \\
& Clerical & 116 & 17.86 \\
& F ratio 4.16 & & $p<.05$ \\
\hline Benefits & Associate & 110 & 17.15 \\
& Technical & 141 & 15.67 \\
& Clerical & 110 & 15.65 \\
& Fratio 3.71 & & $p<.05$ \\
\hline
\end{tabular}

than full-time staff, but the mean scores are in the satisfied range for part-timers and in the dissatisfied range for full-timers. Again, this may reflect an unmet expectation that full-time support staff will be included more in organizational communications.

Table 6 shows that on three of the significant subscales-operational proce- dures, the work itself, and benefits - the ranking of job titles from most to least satisfied is associate-technical-clerical. Yet again, the opposite is found with the communication subscale, where clericals are most satisfied and library associates least, and where the library associates are the only group with a mean score in the dissatisfied range. The 
TABLE 7

JOB SATISFACTION BY LEVEL OF EDUCATION: SIGNIFICANT SUBSCALES

\begin{tabular}{lccc}
\hline & Level of Education & Valid $N$ & Mean \\
\hline Communication & High school & 19 & 16.58 \\
& College degree & 106 & 14.49 \\
& Some college & 131 & 14.15 \\
& Some graduate & 56 & 13.73 \\
& Graduate degree & 56 & 12.70 \\
& F ratio 3.18 & & $p<.05$ \\
\hline Benefits & College degree & 105 & 17.09 \\
& Some graduate & 55 & 16.62 \\
& High school & 18 & 16.39 \\
& Graduate degree & 57 & 16.23 \\
& Some college & 129 & 15.01 \\
& F ratio 3.06 & & $p<.05$ \\
\hline Work itself & High school & 19 & 21.58 \\
& Some college & 131 & 18.66 \\
& Some graduate & 56 & 18.41 \\
& College degree & 107 & 18.23 \\
& Graduate degree & 58 & 18.05 \\
& $F$ ratio 2.72 & & $p<.05$ \\
\hline Promotion & College degree & 105 & 12.31 \\
& High school & 18 & 12.11 \\
& Some college & 131 & 12.07 \\
& Graduate degree & 57 & 11.70 \\
& Some graduate & 56 & 10.77 \\
& $F$ ratio 2.45 & & $p<.05$ \\
\hline & & &
\end{tabular}

results for the first three subscales reflect the common-sense assumption that satisfaction will increase with the increasing level of the position. That staff in associate positions are significantly less satisfied with communication may indicate again an unfulfilled expectation for greater participation in communication at that classification level.

Satisfaction by education has mixed results, as shown in table 7. Supporting the generalizations posited for other variables, those with the highest levels of education are least satisfied with communication and the rewards of the work itself; in both of these subscales, staff with a high school education are the most satisfied. While respondents in all education categories show dissatisfaction with the opportunity for promotion, those with the highest education levels show the most dissatisfaction. These findings suggest that there is a conflict among staff with higher levels of education between the expectation for participation in organizational communications and for promotion opportunities and the actual level of participation and opportunity for promotion in the organization.

In contrast to other studies on job satisfaction in libraries, table 8 shows that support staff who spend the greatest percentage of time working directly with library patrons are significantly less satisfied overall and with operational procedures. While it is true that working with users provides positive rewards and opportunities for immediate gratification, there are also times when public services staff have less control of their work environment. The stress of demands for immediate service and experiences with confused, frustrated, and occasionally even hostile patrons are 
TABLE 8

JOB SATISFACTION BY WORKING DIRECTLY WITH USERS: SIGNIFICANT SUBSCALE AND OVERALL SCALE

\begin{tabular}{lccc}
\hline & Percent Time with Users & Valid $N$ & Mean \\
\hline Overall scale & $0-25$ & 207 & 132.37 \\
& $26-50$ & 50 & 131.18 \\
& $76-100$ & 30 & 127.17 \\
& $51-75$ & 36 & 126.17 \\
Operational procedures & $F$ ratio 5.05 & & $p<.01$ \\
\hline $0-25$ & 232 & 14.25 \\
& $26-50$ & 55 & 13.64 \\
& $51-75$ & 38 & 13.10 \\
& $76-100$ & 39 & 11.97 \\
& $F$ ratio 5.78 & & $p<.001$ \\
\hline
\end{tabular}

part of the job. The dissatisfaction with operational procedures may reflect a feeling that the procedures support staff must follow (though not necessarily participate in formulating) are viewed with less than enthusiasm by some patrons.

\section{Comparison to the Ohio Results}

There are a number of interesting differences in the results of the Michigan study as compared to those of the Ohio study. As discussed, Parmer and East (and others) found that support staff who work in public services and who work directly with patrons were significantly more satisfied than those employed in technical services. In contrast, the Michigan data show that, overall and on operational procedures, the greater the percentage of time spent working directly with patrons, the lower the level of support staff satisfaction. Parmer and East found that satisfaction was significantly lower for staff with more years of experience. Except for the communication subscale, the Michigan data show instead that satisfaction increases with years of experience. Parmer and East found that library assistants and office workers were most satisfied and LTAs least satisfied, while in Michigan library associates are most satisfied and clericals least, except on the communication subscale. Finally, Parmer and East were surprised to find that part-time staff in Ohio were significantly more satisfied than full-time staff on the overall scale and four subscales; but in Michigan, with the exception of communication, full-time staff are more satisfied than part-time on the overall scale and significant subscales.

One possible reason for some of the differences may be that, in coding their data, Parmer and East replaced each item to which staff failed to provide a response with the mean response to the other three items in the subscale. In analyzing the data for the Michigan study, the author used only the completed responses. An examination of Ohio and Michigan support staff position descriptions and salaries may suggest other possible reasons for the differences in findings. Replication of the study in other states may also prove enlightening. Perhaps neither the Michigan data nor the Ohio data are completely representative nationally, but rather some differences may be typical and even inevitable from state to state.

\section{CONCLUSIONS}

The results of this study suggest some possible ways to improve the job satisfaction of support staff. First, whenever organizationally and fiscally possible, efforts can be made to try to ensure the fair compensation of support staff, whose pay levels-no less than those of librarians - should accurately reflect the education and experience requirements 
of the positions they hold. In some libraries where inequities are obvious or seriously suspected, pay equity studies could be conducted in which the compensation for support staff positions is compared to that of other positions within the library, to other campus departments, or to positions outside the university. In other libraries, reclassification studies may be advisable. Librarian supervisors who encourage and work alongside support staff in such endeavors send a clear message to support staff that they are highly valued as important contributors to the library organization.

As an occupational group, librarians frequently find themselves in the unenviable position of having to defend their professionalism to people on the outside. Even when professionalism per se is not an issue, librarianship is often considered a relatively low-status profession, which helps explain why some institutions offer low salaries and why many academic librarians so highly value their faculty status and/or redundantly refer to themselves as "professional librarians." However, in attempting to raise public consciousness about their own professional role, it is possible that librarians inadvertently send a negative message about the status and value of support staff. Indeed, if librarians themselves sometimes feel undervalued, how much more so might the support staff feel? Librarians must not become so in- volved in their own cause that they appear to these employees to discount their dedication and commitment.

This study suggests that insufficient participation in organizational communications and too few contingent rewards, particularly in the form of sincere, positive feedback, are sources of job dissatisfaction for many support staff. Regardless of the management culture of their libraries, whether the Total Quality Management (TQM) model, management by objectives, or another, many support staff seem to feel that they are excluded from the process of decision making and policy development, even when it directly affects them. To remedy this perception, librarians must make every effort to include them in both formal and informal work-related communications.

Support staff are right to think that librarians should genuinely appreciate and value their experiences, points of view, ideas, and opinions. Library administrators must make a concerted effort to ensure that commitment to service and efforts toward problem solving are shared by all staff in their libraries. When such a philosophy of shared responsibility pervades the library organization, this study suggests that the job satisfaction of support staff may increase. As a result, service excellence and growth may be achieved, even in times of budget reductions.

\section{REFERENCES AND NOTES}

1. Larry R. Oberg and others, "The Role, Status, and Working Conditions of Paraprofessionals: A National Survey of Academic Libraries," College \& Research Libraries 53 (May 1992): 221.

2. Association of College and Research Libraries, ACRL University Library Statistics, 1990-91 (Chicago: ACRL, 1992), 20.

3. Sarah M. Pritchard and Eileen Finer, comps., ARL Statistics, 1990-91 (Washington, D.C.: ARL, 1992), 34.

4. Beverly P. Lynch and Jo Ann Verdin, "Job Satisfaction in Libraries: A Replication," Library Quarterly 57 (Apr. 1987): 193.

5. Jack A. Siggins, "Job Satisfaction and Performance in a Changing Environment," Library Trends 41 (Fall 1992): 304.

6. William J. Vaughn and J.D. Dunn, "A Study of Job Satisfaction in Six University Libraries," College \& Research Libraries 35 (May 1974): 177.

7. Steven Seokho Chwe, "A Comparative Study of Job Satisfaction: Catalogers and Reference Librarians in University Libraries," Journal of Academic Librarianship 4 (July 1978): 143.

8. George P. D'Elia, "The Determinants of Job Satisfaction among Beginning Librarians," Library Quarterly 49 (July 1979): 300. 
9. Beverly P. Lynch and Jo Ann Verdin, "Job Satisfaction in Libraries: Relationships of the Work Itself, Age, Sex, Occupational Group, Tenure, Supervisory Level, Career Commitment, and Library Department," Library Quarterly 53 (October 1983): 442.

10. Lynch and Verdin, "Job Satisfaction in Libraries: A Replication," 195.

11. Ibid., 198.

12. Ilene F. Rockman, "Job Satisfaction among Faculty and Librarians: A Study of Gender, Autonomy, and Decision Making Opportunities," Journal of Library Administration 5 (Fall 1984): 55.

13. Carol D. Billings and Betty Kern, "Sources of Satisfaction and Dissatisfaction among Library Paraprofessionals: A Study Based on Fifty Interviews," LLA Bulletin 52 (Spring 1990): 174-77.

14. Donna K. Fitch, "Job Satisfaction among Library Support Staff in Alabama Academic Libraries," College \& Research Libraries 51 (July 1990): 317.

15. Patricia A. Kreitz and Annegret Ogden, "Job Responsibilities and Job Satisfaction at the University of California Libraries," College \& Research Libraries 51 (July 1990): 310-11.

16. Margaret S. Schneider, "Stress and Job Satisfaction among Employees in a Public Library System with a Focus on Public Service," Library and Information Science Research 13 (Oct./Dec. 1991): 393-98.

17. Ibid., 395.

18. Leigh Estabrook, Lisa Mason, and Sara Suelflow, "Managing the Work of Support Staff," Library Trends 41 (Fall 1992): 245.

19. Oberg and others, "The Role, Status, and Working Conditions of Paraprofessionals," 232.

20. Cathleen C. Palmini, "The Impact of Computerization on Library Support Staff: A Study of Support Staff in Academic Libraries in Wisconsin," College \& Research Libraries 55 (Mar. 1994): 122-23.

21. Ibid., 124-25.

22. Coleen Parmer and Dennis East, "Job Satisfaction among Support Staff in Twelve Ohio Academic Libraries," College \& Research Libraries 54 (Jan. 1993): 43.

23. Paul E. Spector, "Measurement of Human Service Staff Satisfaction: Development of the Job Satisfaction Survey," American Journal of Community Psychology 13 (June 1985): 694.

24. Parmer and East, "Job Satisfaction among Support Staff," 47-48.

25. Ibid., 49 .

26. Ibid., 52 .

27. Ibid.

28. Ibid.

29. Ibid., 53 .

30. Ibid., 56 .

31. The Personnel Manual: An Outline for Libraries, 2d ed., ed. Charles E. Kratz and Valerie A. Platz (Chicago: ALA, 1993): 52.

32. Spector, "Measurement of Human Service Staff Satisfaction," 695.

33. Ibid.

34. Ibid., 694 .

35. Ibid., 708 .

36. Vaughn and Dunn, "A Study of Job Satisfaction," 165-66.

37. Parmer and East, "Job Satisfaction among Support Staff," 48. 